\title{
The Development of Sharh\} al-Hadi>th and Its Impact on the Understanding of Hadith in Andalusia; (interpretation of the meaning of aqi>qah and equality of men and women)
}

\author{
$1^{\text {st }}$ Fiki Khoirul Mala ${ }^{1}, 2^{\text {nd }}$ Agus Rifai ${ }^{2}, 3^{\text {rd }}$ Imam Sujoko $^{3}, 4^{\text {th }}$ Ahmad Fudhaili ${ }^{4}$, \\ $5^{\text {th }}$ Hamka Hasan ${ }^{5}, 6^{\text {th }}$ Amany Lubis ${ }^{6}$ \\ \{fiki_mala19@mhs.uinjkt.ac.id ${ }^{1}$, agus.rifai@uinjkt.ac.id ${ }^{2}$, imamsujoko@uinjkt.ac.id ${ }^{3}$, \\ ahmad.fuhaili@uinjkt.ac.id ${ }^{4}$, hamka.hasan@uinjkt.ac.id ${ }^{5}$, amany.lubis@uinjkt.ac.id ${ }^{6}$ \} \\ Sy arif Hiday atullah State Islamic University of Jakarta, Indonesia ${ }^{1,2,3,4,5,6}$
}

\begin{abstract}
The existence of sharah hadith as a part of history cannot be separated from the influence of culture and the social environment. Hadith as one of the legacies of Islam can show its existence in the West, especially in Andalusia. This article will generally show the evidence and role of the existence of sharh\} al-Muwat \}t $\}$ a written in the Islamic world through the understanding of gender equality which is limited in the meaning of aqi $>$ qah. This study uses a literature study and conducting a comparative study of the sharh $\}$ is written by ulama in Andalusia with the theme aqi>qah. The purpose of this paper is to recapture the role of scientists in Andalusia in understanding the contextual of hadith.
\end{abstract}

Keyword: Aqi>qah, Sharh\} al-Hadith, al-Muwat \}t \}a, Islam, Andalusia, Contextual

\section{Introduction}

Hadith as the second source of Islamic law after al-Qur'an [1] is a proposition dalil that shows more flexibility than al-Qur'an,[2] bearing in mind that the hadith contains explanations and legal restrictions that previously stated in the al-Qur'an [3]. The existence of the al-Qur'an which is qat \}'i al-wuru $>d$ in the perspective of Muslims also proves that there is no objection to everything that mentioned in al-Qur'an without the exception of the laws.[4][5][6][7]

This is different from the existence of hadith as an explanation of what is contained in alQur'an because the jurists have stated that the position of hadith when viewed from its arrival and its legal judgment is still zanny al-wuru $>\mathrm{d},[8]$ therefore the tendency of Muslims to acknowledge their position and understanding of hadith also varies. Because the degree of truth of the hadith must go through the steps that have been determined by hadith scholars, in this case, it is known as hadith criticism which includes criticism of sanad and matan. [4]

The characteristics of the hadith, apart from being shown from the perspective of its arrival and its truth, are also viewed from its understanding, this refers to the reality of the situation and the needs of the community at that time, especially when the Prophet Muhammad in conveying several commands and prohibitions on a problem would tend to apply the law which is related to the situation. and the conditions underlying it or in this case is often referred to as contextualization studies.[9][10][11] 
Evidence of the contextualization applied by the Prophet Muhammad in applying the rules to the people of Medina at that time can be seen when the Prophet Muhammad was asked about the best deeds that could be done by the companions and the Prophet answered these questions with different answers.[12][13] just like when the Prophet Muhammad was asked about what the best deeds were, the answers received by the friends at that time were various, including being kind to parents, not being angry, being silent, being kind to neighbors, and so on.

The form of contextualization did not change with the death of the Prophet Muhammad. because this can be examined from the contextualization form of the next generation, namely Umar ibn Khat $\} \mathrm{t}\} \mathrm{a}>\mathrm{b}$. His policy, which always considered aspects of the needs of the people at that time, did not become a strange thing anymore when Umar ibn Khattab decided various policies that were not the same as the Prophet Muhammad, such as not giving zakat to converts, not taking spoils in the form of land during the war, also did not apply the law of cutting off hands.[14][15]

The problem arose again when the hadiths began to be codified during the reign of Umar ibn 'Abd al-'Azi>z. Bookkeeping carried out by Umar ibn 'Abd al-'Azi>z indirectly had an impact on the emergence of a mere textual understanding without considering the practices that had been carried out by the Prophet Muhammad and Khulafah al-Ra>shidi>n.[3] Evidence of the emergence of the understanding of this hadith can be seen from the existence of the al-Z\}a>hiri group founded by Daud al-Z\}a>hiri.[16] The understanding chosen by the al-Z\{a>hiri group subsequently led to opposition to the scholars at that time such as the hadith and fiqh figures, namely Ibn 'Abd al-Barr who strongly opposed the understanding of alZ \}ahiri which was proven through his book, namely Tamhi>d lima $>$ fi $>$ al-Muwatta min alMa'a> ni wa al-Asa>nid. [16] [17]

This research will look at Ibn 'Abd al-Barr's rebuttal to the understanding of hadiths about aqi $>$ qah, namely by answering the sharh \}written by Ibn' Abd al-Barr in his book al-Tamhi>d lima $>$ fi $>>$ al-Muwatta min al-Ma'a>ni wa al-Asa>nid and its contribution to the development of sharh \} al-Muwat\}t an in Andalusia. As for the selection of the book al-Muwat \}t $\}$ a as the main basis of this study, considering that al-Muwat \}t $\} a$ is the work of one of the well-known school scholars in the Islamic world, namely Ma>lik ibn Anas. The capability of Ma>lik ibn Anas in jurisprudence or the practice of religion in Islam is one of the factors that underlie this research which is important to be approached with an understanding of the science of hadith. The main theme studied in this study is the limitation of the number of aqi>qah animals that must be slaughtered when a child is born, the provisions that state that the number of animals slaughtered for boys are two goats and one goat for women indirectly raises the understanding that there is no equality between men and women.

From the above background, the researcher will carry out mapping activities on the development of sharh\}al-Muwat\}t\}a that was written in Andalusia based on the theme aqi>qah. The mapping will then prove the contextualization of hadiths carried out by scholars of hadith in Andalusia. 


\section{Discussion}

\subsection{Sharh\} al-hadi>th and scientific developments in the Islamic world}

In general, the period in the development of sharh $\}$ al-Muwatta according to $\mathrm{T}\{\mathrm{a}>\mathrm{hir}$ alJawwa>bi is divided into three periods, namely the phases of growth, progress, and decline. However, it should be noted that in each of these phases a signatory will not be separated from the preparation phase, laying of its foundations, and the phase of its preparation and implementation. [19]

In the book Juhu>d al-Muhaddithi $>n$, it is generally stated that the period for the emergence and growth of sharah occurred before the fifth century which is marked by the characteristics of sharah which are still simple by only using a language approach and explanation of the difficult traditions that are difficult to understand; in the 5th to 8th-century hijriyah, the writing of sharh \} al-hadi>th how many years was it in its heyday; and starting in the 9th century hijriyah sharh al-hadi> th was in a phase of decline[19]. However, other studies say that the decline phase began in the 11th century.[20]

To prove the phase written by $\mathrm{T}$ \}a $>$ hir al-Jawwa>bi, the researcher will narrow down the reading of sharh \} al-hadi>th al-Muwatta which has been written and can be reread until now, as for the reading hadiths that have been done by researchers of sharh \} al-hadi>th alMuwat \}t \}a which developed in the Islamic world in each period can be seen in the following table:

Table 1. Sharh \} al-Hadi>th al-Muwatta in Periodic of Islam

\begin{tabular}{|c|c|c|c|c|}
\hline No. & Name of Book & Author & Year & Country \\
\hline 1. & $\begin{array}{c}\text { Tafsi>r Gha>rib al- } \\
\text { Muwatta }\end{array}$ & $\begin{array}{c}\text { 'Abd al-Ma>lik ibn Habi>b al- } \\
\text { Sulami }>\text { al-Andalusi }\end{array}$ & $234 \mathrm{~h}$. & Andalusia \\
\hline 2 & $\begin{array}{l}\text { Ghara>ib al-Hadi>th al- } \\
\text { Ima }>\mathrm{m} \mathrm{Ma}>\text { lik ibn Anas }\end{array}$ & $\begin{array}{c}\text { Abu> al-Husein Muhammad ibn } \\
\text { al-Muzfar al-Bazza>r }\end{array}$ & $379 \mathrm{~h}$. & Baghda $>d$ \\
\hline 3. & Tafsi>r al-Muwatta & $\begin{array}{l}\text { 'Abd Allah al-Rahman ibn } \\
\text { Marwan ibn Matraf }\end{array}$ & $413 \mathrm{~h}$. & Andalusia \\
\hline 4. & $\begin{array}{l}\text { Al-Tamhi>d lima> fi al- } \\
\text { Muwatta min al-Ma'ani wa } \\
\text { al-Asa>nid }\end{array}$ & Ibn 'Abd al-Barr & $463 \mathrm{~h}$. & Andalusia \\
\hline 5. & $\begin{array}{c}\text { Al-Istiz }\} \text { ka }>\text { r al-Ja }>m^{\prime} \\
\text { limazhab Fuqaha al- } \\
\text { Ams }\} a>r \text { wa Ulama' al- } \\
\text { Aqt }\} a>r\end{array}$ & Ibn 'Abd al-Barr & $463 \mathrm{~h}$. & Andalusia \\
\hline 6. & Al-Muntaqa & Abu Wali>d al-Ba>ji & $474 \mathrm{~h}$. & Andalusia \\
\hline 7. & $\begin{array}{c}\text { Al-Ta'liq 'ala al-Muwatta } \\
\text { fi> Tafsi>r lughatihi wa } \\
\text { Ghawa>mid I'rabihi wa } \\
\text { Ma'anihi }\end{array}$ & $\begin{array}{c}\text { Hisha }>\text { m ibn Ahmad al- } \\
\text { Waqhishi> }\end{array}$ & $489 \mathrm{~h}$. & Andalusia \\
\hline 8. & Kitab al-Qabas & $\begin{array}{c}\text { Muhammad ibn 'Abd Allah ibn } \\
\text { al-'Araby 7al-Ma'a>rifi }\end{array}$ & $543 \mathrm{~h}$. & Andalusia \\
\hline
\end{tabular}




\begin{tabular}{|c|c|c|c|c|}
\hline 9. & $\begin{array}{c}\text { Al-Masa>lik fi> Sharh }\} \\
\text { Muwatta Ma>lik }\end{array}$ & $\begin{array}{c}\text { Muhammad ibn 'Abd Allah ibn } \\
\text { al-'Araby al-Ma'a>rifi }\end{array}$ & $543 \mathrm{~h}$. & Andalusia \\
\hline 10. & Ittiha>f al-Sa>lik & Ibn Na>sr al-Di>n al-Dimashqy & $842 \mathrm{~h}$. & Baghdad \\
\hline 11. & Tanwi>r al-Hawa>lik & Al-Suyu>ti & $911 \mathrm{~h}$. & Mekkah \\
\hline 12. & $\begin{array}{c}\text { Fath al-Mughatta Sharh al- } \\
\text { Muwatta }\end{array}$ & Al-Mulla Ali al-Qari & $1014 \mathrm{~h}$. & Egypt \\
\hline 13. & $\begin{array}{c}\text { Abhaj al-Masa>lik bi } \\
\text { Sharh\} Imam Ma>lik }\end{array}$ & $\begin{array}{c}\text { Muhammad ibn 'Abd al-Baqy al- } \\
\text { Zarqa>ni }\end{array}$ & $1122 \mathrm{~h}$. & India \\
\hline 14. & Sharh\} al-Lakna>wi & Imam al-Lakna>wi & $1264 \mathrm{~h}$. & Tunisia \\
\hline 15, & $\begin{array}{c}\text { Kashf al-Mughatta min al- } \\
\text { Ma'a>ni wa al-Alfa }>\mathrm{z} \text { wa } \\
\text { al-Wa>qi'ah fi al-Muwatta }\end{array}$ & $\begin{array}{c}\text { Muhamamd T }\{\text { a }>\text { hir ibn } \\
\text { 'A<shu>r }\end{array}$ & 1394 & India \\
\hline 16. & Aujaz al-Masa>lik & $\begin{array}{c}\text { Muhammad Z }\{\text { akariyya al- } \\
\text { Kandhlawi }\end{array}$ & $1406 \mathrm{~h}$. & \\
\hline
\end{tabular}

Based on the table above, the researcher concludes that if sharh \} al-Muwatta also experiences a phase as said by $\mathrm{T}\{\mathrm{a}>\mathrm{hir}$ al-Jawwa>bi, but in the period it needs to be reexamined that sharah al-Muwatta is in a phase of emergence and growth, namely before 5thcentury hijriyah; experienced a phase of progress, namely in the 5th and 6th centuries hijriyah; as well as experiencing its decline phase after the 6th century or in this case starting from the 7th century Hijriyah which was marked by reduced authorship of sharh \}al-Muwatta in the Islamic world. From the table above it can also be reclassified based on the author and the area where the sharah was researched which proves that the sharah al-Muwatta was written by many scholars from Arab regions such as Andalusia and India although it cannot be denied that other regions also contributed such as Baghdad and Egypt. although not as much as Andalusia.

The existence of Andalusia as one of the areas under the Umayyad dynasty had given many influences and developments in various fields of Islamic scholarship. The expansion that continued during the reign of al-Wa>lid ibn 'Abd al-Ma>lik ibn Marwan has led T\{a>riq alZiya $>$ d and Musa> ibn Nas \}r al-Lakhami to open Andalusia as one of the bases of Islamic power in the western area of Muslim rule at that time.[21][22][23][24][25][26]

The very heterogeneous culture of society, as well as the different language and culture from Arab indirectly, also influenced the way of the religion of the Andalusian community, however, the potential of Andalusia as an asset to Islamic progress cannot be eliminated.[27][28][29]. Among the evidence that support this statement include efforts to develop scientific knowledge in the field of fiqh which were marked by the change of schools that occurred in Andalusia, such as the presence of the al-Auza'i school whose influence is almost unknown this century until the al-Z\{a>hiri school of thought which is famous for its textual method of understanding religious propositions, although it cannot be denied that Andalusia also received influence from the four well-known schools of this era, namely the Hanafi, Maliki, Shafi'i, and hambali schools.[30] The presence of four schools of fiqh whose credibility is recognized by Muslims is essentially inseparable from the works produced and developed by their successors. In general, it is not a question anymore if the four schools of thought still survive and are accepted by the majority of Muslims today, including their works which are also researched by world scholars with various backgrounds. [31]

Indirectly examining the understanding of the school by integrating it with the discussion of hadith is a must. The existence of mazhab which is considered as a form of Islamic practice that prioritizes aspects of community needs cannot be separated from hadith as part of the source of law which is the main foothold before a law is implemented. Therefore for the 
people of Andalusia, the position of Imam Ma>lik had a greater influence because of the hadith books he wrote at that time.

Ima $>\mathrm{m} \mathrm{Ma}>$ lik as one of the schools, in reality, can give more role for Andalusia to make scientific contributions as evidenced by the existence of sharh \} al-Muwat \}t \}a, as someone who has credibility in the field of fiqh also writes works that are related to The hadith, namely al-Muwat \}t \}a, of course, became one of the factors of the famous book of al-Muwat \}t \}a and became a reference by scholars at that time. Apart from that, it should also be noted that Imam Malik's life span was between $93 \mathrm{~h}$. - $179 \mathrm{~h}$. It is also another factor that at that time Andalusia was in a period of early development which led many scholars to travel to seek knowledge.[32]

From the above explanation, it can be stated that among the factors that led to Andalusia as a region that had a major impact on the spread of Islam was that Andalusia at that time, namely many scholars traveled to the East to seek knowledge, as well as Andalusia as a western state which had just entered its phase. futu> hat al-Islamiyyah was visited by many scholars to spread Islam. Not only that, but the existence of Andalusia is also strengthened by the establishment of many libraries, which in the Madrasah al-Hadi>thiyyah fi>> Andalus book states that there are more than 50 libraries scattered in Andalusia and is the largest library after Baghdad at that time.[32]

The scientific development in Andalusia is undoubtedly, especially in the field of hadith recitation, furthermore, it will be explained about the periodization of sharh $\}$ al-hadi>th which was written by Andalusian scholars to broaden the discussion and further illustrate the role and evidence of Andalusian scholars in the field of sharh $\}$ al-hadi>th.

\subsection{Period of Sharh\}al-Muwatta in Andalusia}

In general, the periodization in sharh $\}$ al-hadi>th is divided into three, as said by $\mathrm{T}\{\mathrm{a}>\mathrm{hir}$ al-Jawwa>bi, namely the period of emergence and growth; Golden age; and the last is a period of decline. Furthermore, if classified in the Andalusian period, it can be questioned as follows:

Table 2. Sharh\} al-Hadi>th al-Muwatta in Andalusia

\begin{tabular}{|c|c|c|c|}
\hline No & Period & Name of Book & Author \\
\hline 1. & \multirow[b]{2}{*}{ Period of Growth } & Tafsi>r al-Muwat \}t $\} a$ & al-Ma>lik ibn $\mathrm{Habi}<\mathrm{b}$ \\
\hline 2. & & Tafsi>r al-Muwat $\}$ t $\} a$ & $\begin{array}{l}\text { 'Abd Allah al-Rahman ibn } \\
\text { Marwan ibn Matraf }\end{array}$ \\
\hline 3. & \multirow{7}{*}{ Golden Period } & $\begin{array}{l}\text { al-Tamhi>d lima }>\text { fi }>\text { al-Muwat }\} \text { t }\} a \\
\text { min al-Ma'a }>\text { ni wa al-Asa }>\text { nid }\end{array}$ & Ibn 'Abd al-Barr \\
\hline 4. & & al-Tuqs \}a li hadi>th al-Muwatta & Ibn 'Abd al-Barr \\
\hline 5. & & $\begin{array}{l}\left.\text { Al-Istiz }\} \mathrm{ka}>\mathrm{r} \quad \text { al-Ja }>\mathrm{mi}^{\prime} \quad \text { limaz }\right\} \text { ahib } \\
\text { Fuqaha al-Ams }\} a>r \text { wa Ulama' al- } \\
\text { Aqt }\} \mathrm{a}>\mathrm{r}\end{array}$ & Ibn 'Abd al-Barr \\
\hline 6. & & al-Muntaqa> & Abu Wa>lid al-Ba>ji \\
\hline 7. & & $\begin{array}{l}\text { Al-Ta'li>q 'ala al-Muwatt }\}\} \text { a fi }> \\
\text { Tafsi }>\text { r lughatihi wa Ghawa }>\text { mid } \\
\text { I'rabihi wa Ma'anihi }\end{array}$ & $\begin{array}{l}\text { Hisha>m ibn Ahmad al- } \\
\text { Waqhishi>, }\end{array}$ \\
\hline 8. & & al-Qabas & $\begin{array}{l}\text { Muhammad ibn 'Abd Allah ibn } \\
\text { al-'Araby al-Ma'a>rifi }\end{array}$ \\
\hline 9. & & $\begin{array}{llll}\text { Al-Masa>lik } & \text { fi> } & \text { Sharh }\} & \text { Muwatta } \\
\text { Ma>lik } & & & \\
\end{array}$ & $\begin{array}{l}\text { Muhammad ibn 'Abd Allah ibn } \\
\text { al-'Araby al-Ma'a>rifi }\end{array}$ \\
\hline
\end{tabular}


The period of emergence and growth that occurred before the 5th century will find the work of sharah al-Muwatta consisting of us Tafsi>r al-Muwat $\} t\{a$ by 'Abd al-Ma>lik ibn Habi>b and the book of Ghara>ib al-Hadi>th al- Muwatta by Abu> al-Husein Muhammad ibn al-Muzfar al-Bazza>r. From the reading of the two works, it can be seen that the characteristics of the existence of sharh \} al-hadi>th are still very simple, which is limited to explaining words that have difficult meanings and discussing narration which is still very simple.[33] This is in line with what Ta>hir al-Jawwa>bi said that sharah at the time of its emergence and growth did not explain the hadith in much detail but only in terms of the aspects needed.[19]

Referring to developments with history, it can be seen that before the 4th century Hijriyah, Muslims were still in the hadith bookkeeping stage initiated by the ulama called the polarusittah. It can also be seen with the entry of philosophy into Islam which began with the translation of philosophy into Islam and at that time Islamic scholarship was still centered in the Arab world so that the need for sharah was not the main point in scientific development at that time.[34][35][36][37]

The existence of sharh \}began to be recalculated at a time when the Muslim community was progressing and developing, one of which was making Andalusia as the base of the Is lamic power of the Umayyad dynasty at that time, a territory that did not come from Arabic and tended to have a high degree of heterogeneity. Understanding the Arabic language and the knowledge that surrounds it became the main concern of the Andalusian community at that time considering that Islam with all its regulations succeeded in winning the hearts of the people of the area which were previously colonized by various governments such as Rome, Persia, and also the Crusaders who also made slaves and made class social.[11]

Of the various efforts made by the people of Andalusia at that time and their enthusiasm for studying Islam and Islamic science, finally gave birth to sharh \} al-hadi>th al-Muwatta whose writings can still be reviewed to date, as for the sharh \}among them are al-Tamhid lima fi al-Muwatta min al-Ma'ani wa al-Asanid and Al-Istizlka>r al-Ja >mi' limazhab Fuqaha alAms\}a>r wa Ulama' al-Aqt\}a>r by Ibn 'Abd al-Barr; al-Muntaqa by Abu Wa>lid al-Ba>ji; Al-Ta'liq 'ala al-Muwatta fi> Tafsi>r lughatihi wa Ghawa>mid I'rabihi wa Ma'anihi by Hisha>m ibn Ahmad al-Waqhishi>, al-Qabas and Al-Masa>lik fi> Sharh\} Muwatta Ma>lik by Muhammad ibn 'Abd Allah ibn al-'Araby al-Ma'a>rifi.

History states that the fifth and sixth centuries were the heyday of Islam, especially in the Abbasid government because in this century, scientific progress was developing and one of them was Andalusia who also felt this influence if it is drawn from the development of sharh al-hadi> th The needs of the people of Andalusia for sharh \} al-hadi>th are more than those of the Arabs and the Arabs themselves because the culture of society also influences the development of the syarah. In further elaboration that in this century's vulnerability there was no sharh \}al-Muwatta from other regions, which also shows that Andalusia as the basis of scientific development cannot be denied because of the existence of these books is evidence of its progress.[38]

If a review is drawn from these books, it can be seen that the study and discussion of these books are wider than the development of sharah in the previous period. As with al-Tamhi>d lima> fi> al-Muwat\}t \}a min al-Ma'a>ni wa al-Asa>nid written by Ibn 'Abd al-Barr not only to memyarah al-Muwat\}t\}a, as well as The other syarahs in that century that can be examined are that the sharh is indeed more detailed from various perspectives, both from the side of the science of hadith which includes the analysis of sanad and observations which are viewed from the side of hadiths that are accepted and rejected, but also the fiqh side which tends to 
discuss Hadith can be practiced and practiced based on the circumstances and conditions of society at that time.

The period of progress was the last period of the writing of sharah carried out by Andalusian scholars at that time, given that history has recorded that what happened in the 7th century was caused by the Mongol attack on the Muslim world [39][40] also affects the Islamic power in Andalusia, although the attack occurred indirectly, it has an impact on the mental feeling felt by Muslims. As for directly, the factor that destroyed Andalusia was the attack of crosses against the Islamic government in Andalusia, although this was also motivated by the divisions that often occurred between the kingdoms that existed in Andalusia at that time. It is for this reason that Islamic rule in Andalusia is easier to destroy because of the absence of unity and integrity. Therefore, after the 6th century hijriyah sharh $\}$ al-hadi>th, which was the original work of Andalusian scholars, it could no longer be investigated and Andalusia turned into its state until now.

From the previous description, it can be concluded that sharh \} al-hadi>th written by the Andalusian cleric only reached the heyday, even so, the influence exerted by sharah was written at that time is still visible today. Among the evidence that shows this is that sharah at that time was used as a reference by Islamic scholars who lived afterward and still influence today, including the Sahi $>$ h al-Bukha>ri sharh $\}$ written by Ibn Hajar al-Athqala $>$ ni which is a well-known sharh \}in the Muslim community in this century.

\subsection{Aqi>qah and its Interpretation of Gender Equality}

In general, the meaning of aqi>qah is used as a tradition that is carried out after the child is born by the slaughter of the aqi>qah animal. The activity of aqi>qah is indirectly part of a tradition that has developed in Arab society even before Islam came. The term aqi>qah when viewed in language has a special meaning, which is split and something close to the hair, Ibn Fa>ris (390 h.) In his book Maqa>yis al-Lughah states that what is meant by split is that aqiqah is split hair. skin, however, he does not deny the use of other terms such as goat slaughter as well as the meaning of new hair which is marked with the birth of a baby.

The provisions for the division of animals in practice differ from one school to another, as is the case in the perspective of the al-Z\{aa>hiri school of thought which permits the slaughter of two goats for boys while for girls one goat. So that in the conclusion of the al-Z\{a>hiri school of thought, anyone who does not carry out the distribution determined by the text is declared to have deviated from Islamic law. The arguments used by the al-Z\{a>hiri group are as follows:

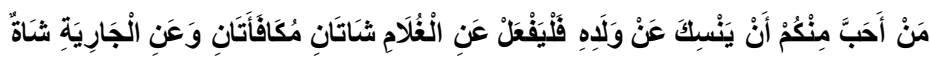

The above argument is also used by groups from Shafi'iyah or followers of al-Shafi'i who argue that the number of aqi>qah animals that must be slaughtered is the same as the provisions stated by the al-Z\{ahiri group, namely two male and female one tail, although in this case Shafi'iyah tends to see this is not part of absolutes to be applied considering that the law of aqi> qah is sunnah, but it needs to be known that if someone has more capability in carrying out aqi> qah then it must be fulfilled according to the sunnah from the hadith.

The al-Ma>liki group or followers of the Maliki school of thought have a different opinion from al-Shafi'I and al-Z \}a>hiri which states that the provisions of aqi>qah animal slaughter between men and women are the same, namely one goat. Also, because the law of aqi>qah is sunnah, Imam Ma>lik in his book al-Muwat \}t \}a also states that there is a recommendation to 
carry out aqi $>$ qah even though only by slaughtering birds. The arguments that show this are as follows:

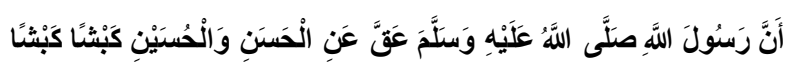

Qata> dah and Hasan al-Basri as first-century scholars in Islam expressed a different opinion from the three schools above, namely by stating that aqi $>$ qah is only practiced for boys but does not need to be implemented for births rather than female babies. The argument used by this opinion is based on the following hadith:

From the various opinions above, it implies that the scholars have different opinions above, it can be concluded that each ulama and mazhab has different opinions in interpreting the existing arguments. Therefore, it is important to look at the sharh $\}$ al-hadi>th approach carried out by the Andalusian scholars.

Sharh \}as one of the written works has characteristics that will describe the background and goals to be achieved by the author, including sharh \}al-Muwat \}t \}a. In historical developments, the scholars have classified the syarahs that have been written by the next ulama to describe generally that sharh \}among these scholars are Ahmad Mujtaba, Isma> 'il Hajj' Abd Allah.[41], Muhammad Alfatih Suryadilaga[42], Nizar 'Ali[43], etc.

The method of writing hadiths if sequenced in general will be found that the writing of sharh $\}$ al-hadi $>$ th is divided into several streams, including sharh $\}$ al-hadi $>$ th tafsi $>l i>$, sharh \} al-hadi>th ijma>li, sharh \} al-hadi>th muqa>rin, sharh $\}$ al-hadi>th thematic and sharh $\}$ alhadi>th lugha>wi. And it should be noted that this division is part of the form of ijtihadi of a Muslim by looking at the works that have been written in the previous period and the possibility of additionality will occur if new work is found that is different from the previous period.[44]

First, sharh \} al-hadi>th tafsi>li> is sharh \} al-hadi>th which will explain the hadith in detail and length from various perspectives, or in other words this sharah is a collection of other sharh\}streams and when combined becoming sharh\} al-hadi>th tafsil besides that, the existence of sharh \} tafsili will always meet the needs of the community both from the general public and even academics.[41] Among the characteristics that can be classified towards the form of sharah tafsil are as follows [42] :

1. The writing is done comprehensively and comprehensively, that is, it contains various kinds of explanations and contents in the hadith to be shedarah.

2. The explanation of the hadith is very broad and usually begins with a word explanation in the meaning of the hadith, without exception explaining the asbab alwuru $>\mathrm{d}$ hadith.

3. Providing a common thread between one hadith and another and the following will make it easier to understand.

4. Describe the understanding of the hadith in depth by taking the opinions and words of scholars who can explain these hadiths, even though in the end sharh $\}$ tends to choose their opinion based on the many opinions presented.

Second, sharh \} al-hadi>th which describes and explains the hadith globally and in general or what is more commonly referred to as sharh \} al-hadi>th ijma>li. The existence of this sharh \}does not explain the hadith in detail but adjusts to the needs of ordinary readers and not academics, sharh \}ijmali usually only briefly describes the understanding of the hadith that will be chanted and rarely expresses the opinions of scholars from various perspectives so that 
indirectly understanding is more partial and less precise. used by readers from academia. As for sharh \} al-hadi>th ijma>li, this is also called thematic sharh \}because it is generally written on a theme and is simple.[45][46]

Third, sharh \}muqa>rin what is often referred to as sharah fiqh. This sharh \}is one of the sharh \} al-hadi>th schools that tend to use the comparison of schools in expressing their sharh by using comparisons, both in the narration of the hadith and the opinions of fiqh scholars who have good competence in the field of religion.[41] In general terms, fiqh sharh \}has the following characteristics [42] :

1. Comparing analytical editorial (mabahiz lafziyyah) and comparison of narrators, the meaning content of each hadith being compared.

2. Discussing the comparis on of various things discussed by the hadith.

3. The comparis on of the opinions of the shyarah covers a very broad scope because the descriptions discuss various aspects, both affecting the meaning of the hadith and the correlation between hadiths and one another.

Fourth, sharh \}lugha>wi, namely sharh $\}$ al-hadi>th which focuses on sharia activities on aspects of language by translating and explaining difficult words from both the sanad and matan perspectives with the aim that readers can understand the hadith personally after knowing the meaning of the language.[47][41]

Of the four syarahs, if applied under the theme aqi>qah and grouped into sharh $\}$ alMuwat $\{\mathrm{t}\{\mathrm{a}$ written by Andalusian scholars, it can be seen as follows:

\subsubsection{Tafsir al-Muwatta karya 'Abd Allah al-Rahman ibn Marwan ibn Matraf}

Tafsir al-Muwatta is one of the sharh al-Muwatta books written in the early days, namely the fourth century of Hijriyah. This work was written by an Andalusian scholar named 'Abd Allah al-Rahman ibn Marwan ibn Matraf.[48]. From the researcher's reading of the theme, aqi $>$ qah in this book, it is stated that Ibn Mat\}raf in mensharh\} al-hadi>th the theme aqi $>$ qah only explains it from a language perspective, namely only mentions hadith and does not explain in good detail by mentioning other narrations from the hadith. or using a fiqh approach by expressing various kinds of opinions from scholars based on existing arguments.

From this explanation it shows that this work is still general by only explaining the opinion of aqi>qah by stating that aqi>qah for men and women is the same. If examined further, it can be stated that the existence of sharh\}written by Ibn Matraf uses the ijmali and fiqh methods, namely by writing sharah in a short, simple manner, but still contains the essence of narrative comparis ons and expressing the views of the schools from various sides.

\subsubsection{The Books by Ibn 'Abd al-Barr}

In general, the book written by Ibn 'Abd al-Barr and has a connection with al-Muwatta consists of three books, namely the book Al-Tamhi>d lima> fi al-Muwat $\}$ t $\}$ a min al-Ma'a>ni wa al-Asa>nid [17] and Al-Istiz\}ka>r al-Ja>mi' limazhab Fuqaha al-Ams \}a $>$ r wa Ulama' alAqt $\} a>r[50]$. From the reading of the two books it states that the book al-Tamhi $>d$ lima $>$ fi $>$ al-Muwatta min al-Ma'ani wa al-asanid and the book Al-Istiz\}ka>r al-Ja>mi 'limazhab Fuqaha al- Ams \}a>r wa Ulama 'al-Aqt\}a>r is closely related, in other words, that the book alIstiz\}ka>r was written after Ibn' Abd al-Barr wrote the book 1-Tamhi>d lima> fi al-Muwat \}t \}a min al-Ma'a>ni wa al-Asa> nid and the book al-Istiz\}ka>r many quote opinions from the book al-Tamhi $>$ d. 
In explaining the concept of aqi>qah Ibn 'Abd al-Barr explains it in detail by using all three approaches at once, namely by mentioning other narrations in the hadith, using the science of hadith, and applying it through sanad and matan criticism; The third uses the fiqh approach, namely by mentioning the various opinions of scholars regarding the concept of limiting slaughtered animals for aqi $>$ qah. From the application of the three approaches, it can be seen that Ibn 'Abd al-Barr does not support one opinion with another.

In general, Ibn 'Abd al-Barr has a concept of understanding which states that as long as the hadith is not gharib, that is, other narrations support this statement, it is still accepted in Ibn' Abd al-Barr's perspective. This can be proven from the statement of Ibn 'Abd al-Barr who commented on and criticized the opinion of Qata>dah and Hasan al-Bas \}ri who stated that aqi $>$ qah was only for men with the opinion of hadith.

The description above shows that Ibn 'Abd al-Barr in his two works using the muqarin method but in more detail regarding the use of narration and also the elaboration of the opinions of the scholars, and if it is traced with the existing syarah, Ibn Matraf's work can be seen that the development of sharah is visible. more clearly, namely, in the previous period, sharah was still simple while the later phases were even wider.

\subsubsection{Sharh\} al-Hadi>th by Abu> Wa>lid al-Ba>ji}

Sharh \} written by Abu> Wa>lid al-Ba>ji entitled al-Muntaqa>.[51] In the opening of the book, Abu Wa> lid al-Ba>ji stated that the background for the writing of sharh $\}$ which was named Al-Munta> qa> because the author saw the phenomenon of shifting hadith that was too detailed by describing various aspects of sharia both from the perspective of sanad and eyes. resulting in the difficulty of readers of the general public in studying the main purpose of the sharh $\}$ which was written. From this background, Abu> Wa>lid al-Ba>ji wrote his syarah by focusing on the general aspects of the meaning of the book al-Muwat \}t $\}$ a to make it easier for the reader, especially the general public to understand the hadith that Imam Malik had written in the first half of the century the second hijrah.

Kitab al-Muntaqa $>$ indirectly refutes the statement that during the heyday of the sharh $\}$ alhadi>th penitentiary, it has broad and detailed characteristics, considering that sharh is general and does not contain many explanations except for those that are important and needed by the general public.

Aqi $>$ qah in the perspective of $\mathrm{Abu}>\mathrm{Wa}>\mathrm{lid}$ al-Ba>ji shows that $\mathrm{Abu}>\mathrm{Wa}>\mathrm{lid}$ al-Ba $>\mathrm{ji}$ follows the opinion of Ima $>$ m Ma>lik ibn Anas which states that in the removal of aqi $>$ qah there is no difference between male and female and both get the same provisions, namely one goat. However, if it is further investigated that the book al-Muntaqa> does not use the must \}alah hadith approach, namely the criticism of sanad and matan, only uses the narrative and fiqh approaches, therefore the conclusions given by $\mathrm{Abu}>\mathrm{Wa}>\mathrm{lid}$ al-Ba $>\mathrm{ji}$ tend to be put forward the fiqh side rather than the hadith.

\subsubsection{The Books of Hisha>m ibn Ahmad al-Wa>qishi}

Al-Ta'li> q 'ala al-Muwatta $f i>$ Tafsi>r Lugha>tihi wa Ghawa> mid I'rabihi wa Ma'anihi is a work written by Hisha> $m$ in the last half of the fifth-century hijriyah,[52] Meanwhile, if viewed in the language of the name of the book, it means that the book will explain the book al-Muwatta from the perspective of the language both regarding the meaning and also the language rules. Then the researcher reread the work and found that the book had the following characteristics: 
1. Choosing words that have foreign and general meanings for further explanation in the process of shifting.

2. Explain the meaning of Arabic in detail by mentioning synonyms as a form of explanation

3. Using linguistic principles in describing the syarh to expand the study of sharia

4. Reinforce with exposure to syi'ir who are related to the explanations.

From the description above, it can be seen that this sharh $\}$ uses a very detailed linguistic method and does not use other methods to explain detailed rules in the field of law as described by previous scholars.

In mensharh $\}$ al-hadi> th which has a relationship with aqi>qah, Hisha>m ibn Ahmad alWa>qishi does not explain it in a written book so that the researcher cannot see the characteristics of sharh \} written in the theme aqi>qah.

\subsubsection{The Books by Muhammad ibn 'Abd Allah ibn al-'Araby al-Ma'a>rifi}

al-Qabas[53] and al-Masa >lik fi>> Sharh\} Muwatta Ma >lik [54] are two books written by Muhammad ibn 'Abd Allah ibn' Araby al-Ma'a>rifi in the sixth-century hijrah. The two books have the same characteristics from the perspective of their main content, namely that they both explain the sharh of the book al-Muwatta from the perspective of fiqh and its fiqh proposals.

The difference that can be seen between the two is that the book al-Masa>lik fi>> Sharh \} Muwat \}t \}a Ma>lik has a wider study than the book al-Qabas because in its translation the book al-Masalik also explains from its sanad perspective while the book al-Qabas is only sufficient to explain In terms of fiqh and fiqh proposals, in other words, the book al-Qabas uses the flow of ijma> li and the book al-Masa>lik fi>> Sharh \} Muwatta Ma>lik uses the tafsi> li> flow.

In explaining aqi>qah, Ibn al-'Araby al-Ma'a>rifi uses the fiqh approach and narration in the book al-Masa>lik fi> Sharh\} Muwatta Ma>lik and uses the linguistic approach in the book al-Qabas. Indirectly from these two books, it will conclude that Ibn al-'Araby al-Ma'a>rifi strengthens the opinion of Ima $>\mathrm{m}$ Ma $>$ lik by supporting the statement that aqi $>$ qah between men and women is the same, namely one goat.

\section{Conclusion}

From the above explanation, it can be concluded that the existence of sharh \} written by Andalusian scholars is various and the theory stated by $\mathrm{T}$ \}a $>$ hir al-Jawwa>bi is not valid considering that it can be seen in the period of writing sharh \} al-Muwatta does not limit that sharh al-hadi>th in the early days tended to be simple and followed by sharh which had more complex writing, but sharh \} was part of the writer's subjectivity in writing it.

The existence of sharh \} al-hadi>th as one of the works that cannot be separated from the development of Islam is not limited by place, this is evidenced by the existence of sharh $\}$ alMuwatta which tends to show its development in the Andalusian daetah. Also, sharh\} authorship is essentially motivated by the needs of Muslims at any time which changes from one state to another, therefore it can be seen and concluded that sharh $\}$ al-hadi>th can be written in various methods and schools depending on the needs. writer and society at that time. 
From the limitation of the problem with the theme sharh f from aqi>qah it can be concluded that sharh \} which uses all three approaches at once, namely by mentioning oth er narrations in the hadiths, criticizing the traditions and observations of hadith, and mentioning various kinds of differences of opinion of fiqh scholars will lead one to a better understanding. It is more comprehensive and does not fall into bigotry, while sharh \} which is written using only a linguistic or fiqh approach, and narration tends to lead to a fanatical understanding of certain mazhab. 


\section{References}

[1] M. Al-Siba'iy, Al-Sunnah wa Maka>natuha> fi> al-Tashri>' al-Isla>miy. Kairo: Da>r alSala>m, 2017.

[2] M. Shahru>r, Al-Kita>b wa al-Qur'an; Qira $>a h$ Mua> 'as\}irah. Damaskus: Al-Ahaly li alTaba>'ah wa al-Nas \}r wa al-Tauzi>'.

[3] M. M. Abu> Zahw, Al-Hadi>th wa al-Muhaddithu>n aw 'Ina $>$ yah al-Ummat al-Isla $>$ miyah bi al-Sunnah al-Nabawiyah. Riya $>$ d \}: Al-Ria>sah al-'Ammah li al-Ida>rah al-Buhu >th al-'Ilmiy yah wa al-Ifta> wa al-Da'wah wa al-Irsha>d, 1984.

[4] 'Abd al-Wahha>b Khalla>f, 'Ilm Us $\} u>l$ al-Fiqh. Kairo: Maktabah al-Da'wah al-Isla>miyyah Shaba>b al-Azhar, 1956.

[5] A. I. Al-Sha>tiby, Al-Muwa $>$ faqat fi $U s\} u>l a l-A h k a>m$. Beirut: Da>r al-Fikr.

[6] M. S. Maz\}ku>r, Al-Madkhal li al-Fiqh al-Isla>mi. Kairo: Da>r al-Nahdah al-Arabiy ah, 1966.

[7] M. M. Al-Salabi, Al-Madkhal fi> al-Ta'ri>f bi al-Fiqh al-Isla $>m i$. t.tp: Da>r al-Ta'li>f, 1996.

[8] M. Al-Faylani, "Muqa $>$ rabah li al-Istidla $>1$ al-Z\{anny wa al-Qat $\}$ 'i fi $>$ Mana $>$ hij ba'du 'Ulu>m al-Insa>niyyah," Al-Majjalh al-Dauliyah li al-Dira>sa>t al-Isla>miyyah alMutakhas\}s\}is\}ah, vol. 2 No. 2, pp. 139-147, 2019.

[9] A. Duderija, "Evolution in the Canonical Sunni Hadith Body of Literature and the Concept of an Authentic Hadith During the Formative Period of Islamic Thought as Based on Recent Western Scholarship," J. Arab Law Q., vol. 23 No. 4, pp. 389-415, 2009.

[10] A. Zysow, "The Economic of Certainty : An Introduction to the Typology of Islamic Legal Theory," Harvard University (Ph.D Dissertasion) 1984, 2013.

[11] M. khalid Masud, "A History of Islamic Law in Spain: An Overview," Islam. Studeis by Islam. Res. Institute, Int. Islam. Univ., vol. 30, no. Muslim Herritage, pp. 7-35, 2020.

[12] A. 'Abd A. M. I. I. Al-Sha>fi'i, Al-Risa >lah. Beirut: Da>r al-Kutub al-'Ilmiy y ah.

[13] N. A. Al-Safdy, "Al-Ima>m al-Sha>fi'i wa 'Ilm Mukhtalif al-Hadi>th," Gaza.

[14] M. Y. Al-Qard\}a >wi, Dira>sa>t fi> Fiqh Maqa>s\}id al-Shari> 'ah. Kairo: Da>r al-Shuru>q, 2007.

[15] M. Ridwan, "Implementasi Syariat Islam: Telaah atas Praktik Ijtihad Umar bin Khattab," Tsaqafah Unida Gontor, vol. 13 No. 2, pp. 231-254.

[16] M. A. Qa>diri, "Ta'qi>ba>t al-Ha>fiz $\}$ Ibn 'Abd al-Barr 'ala Ahl al-Z $\{a>$ hir min khila $>1$ Kita>bihi al-Tamhi>d," Ahmad Dara>y ah University, Al-Jaza>ir, 2017.

[17] A. U. Y. ibn 'Abd Allah ibn M. Ibn 'Abd al-Barr al-Namary al-Qurt \} $\mathrm{u}>$ by al-Andalusy, $A l$ Tamhi $>$ d lima $>$ fi $>$ al-Muwat\}t\}a min al-Ma'a $>$ ni wa al-Asa $>$ nid. London: Muassasah al-Furqa $>\mathrm{n}$ li al-Tura $>$ th al-Isla>my, 2017.

[18] S. al-D. A. 'Abd A. M. ibn A. ibn 'Uthman ibn Q. Al-Zahabi, Siyar A'la>m al-Nuba>la>. Beirut: Muassasah al-Risa>lah, 1982.

[19] M. T\{. Al-Jawwa>bi, Juhu>d al-Muhaddithi>n fi> Naqd Matan al-Hadi>th al-Nabawi alShari>f. Tunisia: Muassasah 'Abd al-Kari>m ibn 'Abd Allah, 1986.

[20] I. Ahmad, "Pola Pen-Sharh-an Hadis; Studi Metodologi pada Karya-karya Nawawi alBantani," Sekolah Pascasarjana UIN Syarif Hiday atullah Jakarta, 2018.

[21] A. Al-Qud\}a>t, Madrasah al-Hadi>th fi> al-Basrah Hatta al-Qarn al-Tha>lith al-Hijriy. Beirut: Da>r Ibn Hazm, 1998.

[22] T. al-S. Al-Yuzbaky, "Al-Had $\} a>$ rah al-Isla $>$ miyyah fi $>$ al-Andalus wa Atha $>$ ruha $>$ fi $>$ 'Uru>ba," J. Thaqafatuna li al-Dira $>$ sa $>t$ wa al-Buhu>th, vol. 5, no. 20, pp. 119-148, 2010.

[23] J. H. Shannon, "Performing al-Andalus, Remembering al-Andalus : Mediterranean Soundings from Mashriq to Maghrib,” J. Am. Folk., vol. 120, no. 477, pp. 308-334, 2007.

[24] M. 'Abd A. Ghina>n, Daulah al-Isla>miyyah fi> al-Andalus, Cet. 4. Kairo: Maktabah alKhanji, 1997.

[25] Z. Broqunsal, Levy; Terj Qarqut, Had\}a>rah al-'Arab fi> al-Andalus. Beirut: Dar Maktabah bi al-Haya.

[26] A.-M. ' Al-Wahid, Al-Mu'ji>b fi> Talkhi>s Akhbar al-Maghrib' min ladun Fath al-Andalus 
'ila Akhi>r 'As\}r al-Muwahhidu>n. Kairo: Da>r al-Istiqa>mah, 1949.

[27] I. G. Sa'id, "The Heritage of al-Andalus and The Formation of Spanish History and Identity," Int. J. Hist. Cult. Study, vol. 3, no. 1, pp. 63-76, 2017.

[28] M. R. Menocal, "Visions of Al-Andalus," in The Literature of Al-Andalus, United Kingdom: Cambridge University Press, 2000, pp. 1-30.

[29] M. 'Abdo Hatamleh, Al-Andalus; History, Civilization, and Affection (A Complete Study). Jordania: Matabi' al-Dustur al-Tijariy ah, 2000.

[30] A.-Q. 'Iy ad \}, Tarti $>b$ al-Mada $>$ rik. Maroko: Al-Mamlakah al-Maghribiy ah.

[31] M. A. al-M. Abd al-Maji>d, Al-Ittija $>h a>t$ al-Fiqhiyyah 'inda As $\} h a>b$ al-Hadi $>$ th fi> alQarn al-Tha>lith al-Hijriy min Us\}u>l al-Fiqh wa Qawa>'idiha>. Kairo: Maktabah al-Khanji, 2016.

[32] M. M. Hamidatoo, Madrasah al-Hadi>th fi> al-Andalus. Beirut: Da>r Ibn Hazm, 2007.

[33] H. H. Ubaidah, "Kajian Sharh\} al-hadi>th (Studi Teks Kitab Misbah al-Zalam Syarh Bulugh al-Maram min Adillati al-Ahkam)," UIN Syarif Hiday atullah, 2019.

[34] H. Nasution, Falsafat dan Mistisme dalam Islam. Jakarta: Bulan Bintang, 1973.

[35] M. A. Al-Jabiri, Takwi>n al-'Aqli> al-'Araby. Markaz al-Thaqafi> al-'Arabi, 1991.

[36] L. Gardet, Falsafah al-Fikr al-Di>i. .

[37] 'Ali Sa>mi al-Nashsha>r, Nash'at al-Fikr al-Falsafi fi>> al-Isla>m. Kairo, 1997.

[38] A. al-'Abbas A. ibn M. Ibn 'Azary, Al-Baya $>n$ al-Maghri $>b$ fi> Ikhtis\}a $>r$ Akhbar Mulu $>k$ al-Andalus wa al-Maghri $>b$. Tunisia: Da $>\mathrm{r}$ al-Gharab al-Isla $>$ my, 2013.

[39] A. S\{alabi, Mawsu>'ah al-Ta>rikh al-Isla>mi wa al-Had\}a>rah al-Isla>miyah. Kairo: Maktabah al-Nahd $\}$ ah al-Misriy yah, 1985.

[40] Al-Z \{ahabi, Ta>rikh al-Isla $>m$. Beirut: Da $>\mathrm{r}$ al-Kutub al-'Araby, 1987.

[41] A. al-M. Banaqa and I. H. 'Abd Allah, "Manha>jiyyah Sharh\} al-Hadi>th: As \}a $>$ lah wa Mu'a>s \}irah," Al-Tajdi>d, al-Ja>mi'ah li al-Isla>miyah al-'Alamiyyah Malaysia, vol. 16 No. 33, pp. 159-196, 2012.

[42] M. A. Suryadilaga, Metodologi Sharh\} al-hadi>th : Kalsik Hingga Kontemporer. Yogyakarta: SUKA-Press UIN Sunan Kalijaga, 2012.

[43] N. Ali, Memahami Hadis Nabi; Metode dan Pendekatan. Yogy akarta: Alfath Offset, 2001.

[44] B. Ibn Kholi $>1$ al-S $\{$ afdi and N. ibn H. Hama $>$ d, "'Ilmu Sharh $\}$ al-Hadi $>$ th; Ta'ri $>$ fuhu wa Ahamiy ya>tuhu wa Nashatuhu wa Aqsa>muhu wa Mana>hijuhu wa Maud \}u> 'uhu wa Masa>iluhu," IUG J. Islam. Stud., vol. 24, no. 1, pp. 77-46, 2016.

[45] H. 'Abd al-A. Sultani, "Al-Sharh\} al-Maud \}u>'i: Dira>sa>t Maudu>' Mu'ay y an fi > D \}ou' alSunnah al-Nabawiy yah wa Maqa>sidiha $>$ min Khila $>1$ Hadi>th au Atha $>$ r li al-Wus \}u $>1$ ila Ru-yah Hadi>thiy yah Mutaka>milah Tija>hahu," Al-Ja>mi'ah al-Isla>miyah al-'Alamiyyah, Malaysia, 2007.

[46] A. ibn 'Abd al-Q. 'Aziy, "Manha>j al-Muhaddithi>n fi $>$ Sharh $\}$ al-Hadi>th," Malay sia.

[47] N. Ali, "Kontribusi Imam Syekh Nawawi dalam Penulisan Sharh\} al-hadi>th ( Kajian atas Kitab Sahih Muslim bi Sy arh an-Syekh Nawawi)," Disertasi UIN Sunan Kalijogo, 2007.

[48] A. al-M. 'Abd al-R. ibn M. Al-Qunazi'i al-Qurt \}u $>$ bi al-Andalusi, Tafsi $>r$ al-Muwat $\}$ t\}a. Qatar: Al-Haiah al-Qatariy yah li al-Auqa>f.

[49] A. U. Y. ibn 'Abd Allah ibn M. Ibn 'Abd al-Barr Al-Namary al-Qurt \}ubi al-Andalusy, AlTuqsa> lima $>$ fi> al-Muwat\}t\}a min Hadi>th al-Nabi. Kuwait: Al-Wa'i al-Isla>mi, 2012.

[50] A. U. Y. ibn 'Abd Allah ibn M. Ibn 'Abd al-Barr Al-Namary al-Qurt\}ubi al-Andalusy, AlIstiz\}ka>r al-Ja>mi' li Maz\}a>hib Fuqaha al-Ams\}a>r wa 'Ulama al-Aqt\}a>r. Kairo: Da>r alWa'yu, 1414.

[51] A. W. S. ibn K. Al-Ba>ji al-Andalusy, Al-Muntaqa Sharh\} al-Muwat\}t\}a.

[52] H. ibn A. Al-Waqishi al-Andalusy, Al-Ta'li>q 'ala al-Muwat\}t\}a fi> Tafsi $>r$ Lugha>tihi wa Ghawa >mid I'ra >bihi wa Ma'a $>$ nihi. Riy a>d\}: Maktabah al-'Ubaikan.

[53] A. B. M. ibn 'Abd A. ibn al-'Araby Al-Ma'a>rifi, Kita $>b$ al-Qabas. Beirut: Da>r al-Gharab al-Isla>my, 1992.

[54] A. B. M. ibn 'Abd A. ibn al-'Araby Al-Ma'arifi, al-Masa>lik fi> Sharh\} Muwat\}t\}a Ma>lik. Beirut: Da>r al-Gharab al-Isla>mi, 2007. 
